\title{
William Peter Crowcroft (1922-1996)
}

The death of Peter Crowcroft on 10 August 1996 marks the end of a remarkable career. Peter was a mammalogist, ecologist, ethologist, and above all a scholar. His unorthodox professional life spanned three continents, and encompassed full doses of research, administration, public service, and education. To all of these endeavors he brought competence, ingenuity, selflessness, vigor, and humor. His was a life about which there can be few regrets, except that it ended too soon. Bone marrow cancer caused an unexpected and precipitous decline in his health only a few months before his death.

Crowcroft was born in Launceston, Tasmania, Australia, on 27 October 1922. He attended the University of Tasmania from which he earned both Batchelor's (1944) and Master's (1948) degrees. Based on his M Sc research he published 11 papers over the next few years on helminth parasites occurring mostly in Tasmanian fish. These included the description of a number of new species and one new genus of trematode Choanomyzus. With his first wife Ingeborg and with an Overseas Fellowhip, Peter then left for Oxford University to pursue a Philosophiae Doctor's degree in the Bureau of Animal Population with Charles Elton and H. N. (Mick) Southern. It was here that he began his life long involvement with the ecology and behavior of small mammals, particularly shrews and house mice Mus musculus. He completed his degree in 1954.

In 1952 Peter married Gillian K. Godfrey, a fellow mammalogist and student at Oxford. From 1951 to 1956 he was employed as a Senior Scientific Officer in the Infestation Control Division of the Ministry of Agriculture and Fisheries, London. In this capacity he worked on the control of house mice in agriculture. Apparently disallusioned by the bureaucratic inefficiencies of government work and the decline in the intellectual challenges of his research (R. J. Berry, pers. comm.), he resigned to accept a position as Principle Scientific Officer in the Mammal Section of the British Museum (Natural History). He served in this capacity from 1956 to 1961, and it was during this time that he made a number of collecting trips to the former Southern Rhodesia and also initiated his long association with Polish science. He made numerous trips to Poland between 1959 and 1961 (Fig. 1), and in August-September 1960 he attended the first Symposium Theriologicum held in Brno, a conference which later evolved into the International Theriological Congresses.

Peter accepted in 1962 a position as Director of the South Australian Museum in Adelaide, a position he kept for six years (1968). During this period he became one of the founders of the Australian Mammal Society and was engrossed in 


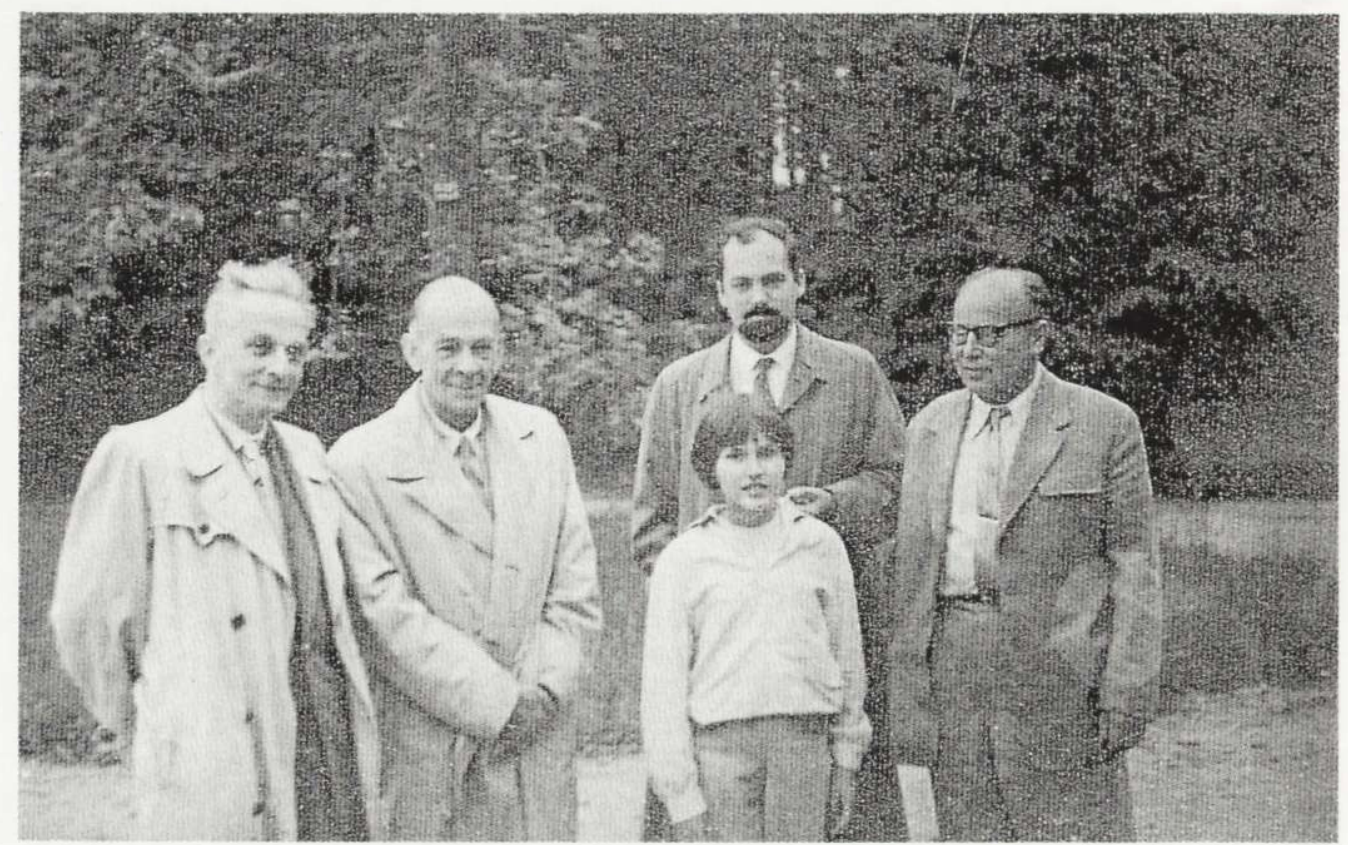

Fig. 1. A distinguished assemblage of shrew biologists, Białowieża, Poland, in May 1959. Left to right (adults): Georg H. W. Stein, Klaus Zimmermann, Peter Crowcroft, and August Dehnel.

research on the hairy-nosed wombat Lasiorhinus latifrons. The Museum prospered under his guidance, with a massive reorganization of its exhibit program and a general increase in the public's access to its resources.

He was offerred in 1968 the position of Director of the Brookfield Zoo (Chicago) and President of the Chicago Zoological Society. Thus, began the North American and zoological garden portions of his career. In his seven years at Brookfield he succeeded in rebuilding the zoo physically and financially, raising it once again to the front ranks of major zoos. He kept his academic connections through an Adjunct Professorship in Zoology at the University of Chicago. During this period he married Lisette K. Whitcombe, a native of South Australia. In 1975 he returned to Australia to manage the Taronga Park Zoo in Sydney, and to build a new open-range zoo in Dubbo (New South Wales). Here too he succeeded in modernizing this famous institution. Four years later (1979) he returned to North America as Assistant Director of the Metro Toronto Zoo and Honorary Professor in Zoology at the University of Toronto, becoming Director in 1981.

At this stage in his life Peter was motivated to become an American citizen so he searched for an appropriate position in the United States. In July 1983 he moved to Salisbury, Maryland, to become Director of the Salisbury Zoological Park (Fig. 2). Once again he succeeded in making major improvements in this small-city 


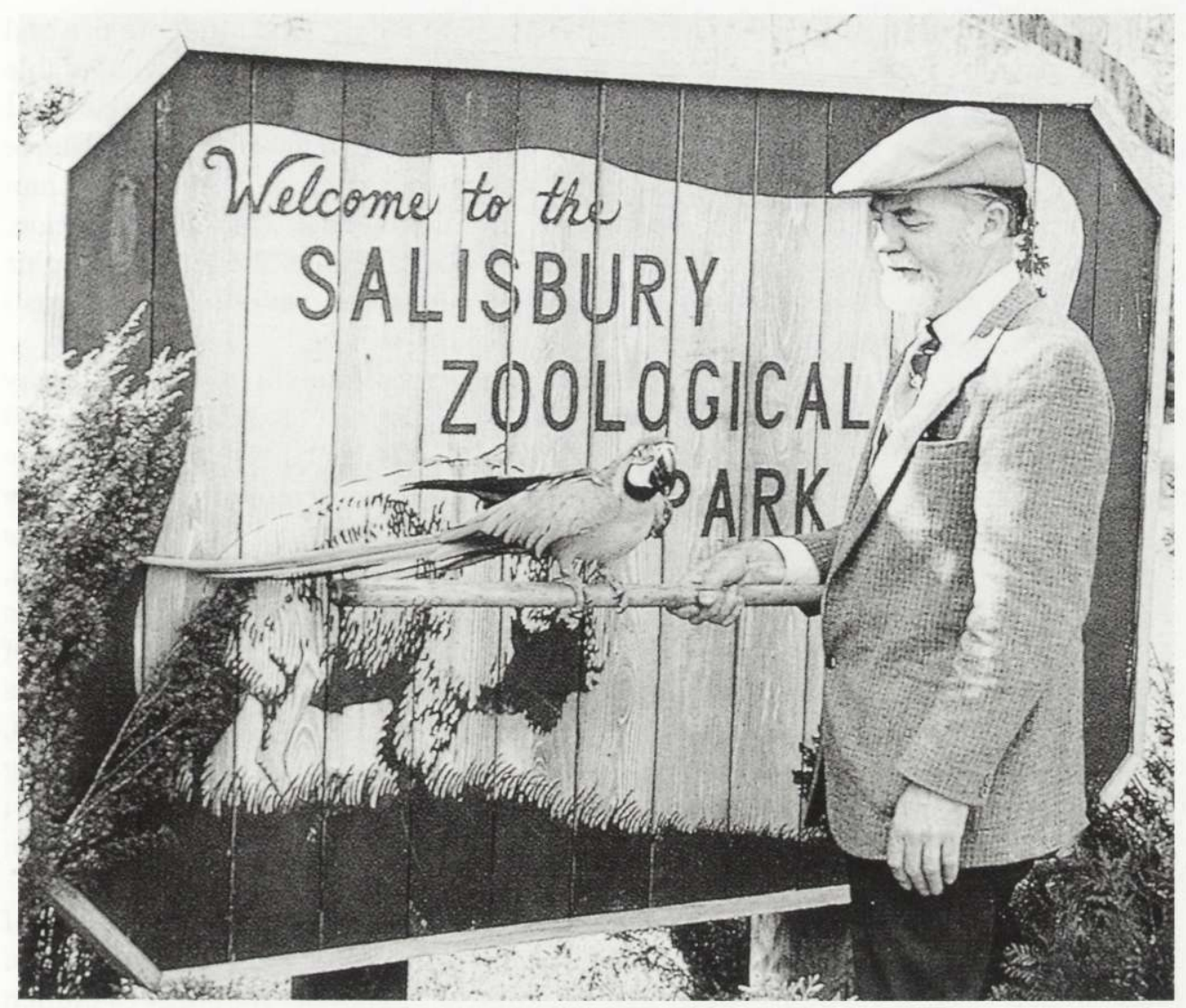

Fig. 2. Peter Crowcroft as Director of the Salibury Zoological Park, Salisbury, Maryland, USA. Photo by Rick Maloof, taken in 1987 and reproduced here with the photographer's permission.

zoo doubling its attendance and revenues. His goal of becoming a US citizen was achieved on 17 September 1987. One of us (WZL) once asked Peter why he changed jobs so often. He said that his philosophy was to take on a job, give it his best effort, and then once a positive impact was made to move on to another opportunity. He was certainly true to this principle, although the intellectual challenge of new horizons was also likely a motivating factor.

In 1989, at the age of 67, Crowcroft began the university teaching phase of his career. He moved to Austin, Texas, and joined the Department of Zoology at the University of Texas as a Lecturer. He taught throughout the academic year and often in summer as well. Sometimes he complained that he could not attend some professional meeting or other because he had to work to support his family. His teaching efforts were challenging, but from all reports he rose magnificently to 
the task. Not only did he enjoy it immensely, but both faculty and students praised his efforts proclaiming him one of the most entertaining and knowledgeable teachers at the university. After Peter died, a graduate student wrote a lament in the student newspaper saying "He was one of the most wonderful people I have ever met ... He was, and still will be, a great inspiration to me." On more than one occasion he commented on the pleasures and demands of this new vocation. For example, he mentioned how hard he had to work to learn modern molecular biology which of course did not exist when he was an undergraduate. He was still teaching summer school when stricken with his fatal illness.

It is difficult to summarize such a diverse and successful career except to say that it took courage, energy, and diverse talents. Although research was a small part of it, he published at least 53 papers including six books. Three books were semi-popular accounts of his investigations on shrews, house mice, and moles (the last with his second wife Gillian). A small book on Australian marsupials was published in 1970. Another book grew out of his experiences as director of zoos, and reportedly prompted Mick Southern to remark that if Crowcroft could make managing zoos so interesting he would be the proper person to write a history of the Bureau of Animal Population at Oxford (Crowcroft 1991: xi). With Charles Elton's encouragement, this was the subject of his last book: "Elton's Ecologists, a history of the Bureau of Animal Population" (Crowcroft 1991). He was planning to write at least two additional books, one on his adventures in Africa and one on Geoffrey Watkins Smith, a British zoologist who worked extensively in Tasmania, but was killed in World War I.

Crowcroft's first papers on mammals were two notes in the Journal of Mammalogy in 1951 about live trapping shrews and keeping them in captivity. These papers, along with those of A. Dehnel and O. P. Pearson, did much to launch the modern study of shrew biology from the then prevailing mystique that shrews were physically weak creatures prone to die of fright. At this time August Dehnel (Białowieża) was engaged in extremely important pioneering work on shrews, publishing four major papers between 1949 and 1952 (Pucek 1964). Because Dehnel described rather surprising discoveries about seasonal changes in shrew morphology, and possibly because his results were published in Polish, Crowcroft and other shrew biologists did not at first take them seriously. Although these papers had summaries in English or German, the summaries deteriorated in quality and length through the series, the first being excellent. Each of the three English summaries contains mis-translations of "over-wintering" to "hibernation" (or similar term), and it is possible that this contributed to a disbelief in Dehnel's findings (Dehnel 1949: 94, 1950: 53, 55, 1952: 375). However, Dehnel's comprehensive understanding of shrew life history is readily apparent to anyone who examines these classic papers. When Peter published his first book "The life of the shrew" in 1957 he failed to reference Dehnel's contributions. However, after he and others had corroborated Dehnel's findings (Pucek 1955, 1957, Caboń 1956, Schubarth 1958, Crowcroft and Ingles 1959), and after he visited Dehnel, he 
realized his unfortunate mistake. Subsequently, Crowcroft and Dehnel planned joint research projects (Crowcroft 1964), but Dehnel's premature death (1962) prevented their fruition. Subsequently, Crowcroft paid tribute to Dehnel's contributions at every opportunity; see for example his dedication (Fig. 3) to Dehnel of his book "Mice all over" (Crowcroft 1966). At about the same time that Peter visited Dehnel he also met Kazimierz Petrusewicz (Lidicker 1984) at Oxford which also led to a series of fruitful interactions (Andrzejewski et al. 1959, Andrzejewski 1984). His interactions with both men as well as many other Polish scientists spawned his life-long interest in Polish mammalogy and ecology. Much later (1985) he was one of the prime movers in the establishment of the Dehnel-Petrusewicz Memorial Fund (Crowcroft 1987), which continues to assist Polish mammalogists and ecologists in attending international meetings, particularly the International Theriological Congresses. The Fund has an executive committee and a Polish advisory commitee, the latter providing advice on the disbursement of funds. Peter served as Secretary/Treasurer of this Fund until June 1995. One of his frustrating

\section{MICE ALL OVER}

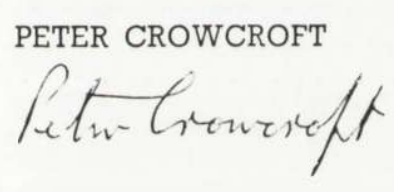

PETER CROWCROFT

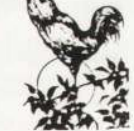

LONDON

G. T. FOULIS \& CO LTD

I-5 PORTPOOL LANE E.C.
In fond meinory

of

AUGUST DEHNEL

"Kung of the Shruews

imperor of Bratenuza

Fig. 3. Crowcroft's autographed dedication of a copy of his book "Mice all over" (1966) to August Dehnel (library of the Mammal Research Institute, Polish Academy of Sciences, Białowieża, Poland). 
but eventually successful tasks during this period was achieving tax exempt status for the organization.

Crowcroft's involvement with the D-P Fund was but one example of the service-orientation he exemplified throughout his life. Helping organizations to do their job better, assisting colleagues, and inspiring students were all central themes in his life's work. His views about the role of zoos and his writing of semi-popular books and articles further signaled his connections with humanity at large. He was active in the cause of conservation, one tangible result of this was the purchase in 1971 by the Brookfield Zoo of a property in South Australia, now known as the Brookfield Conservation Park, in an effort to preserve habitat for the hairy-nosed wombat. Aside from his memberships in professional organizations like the American Society of Mammalogists, the Australian Mammal Society, and the British Mammal Society, the other organization that had special meaning for Peter was the Zoological Society of London. He tried to attend meetings of its Zoological Club as often as possible. These kept him in touch with his British intellectual roots (as well as with miscellaneous nomadic colleagues from around the world), and also served as opportunities for him to visit his three sons who lived in Britain.

Peter Crowcroft is survived by his wife Lisette and by six sons: Peter Jr, James, Simon, Christopher, Paul, and Noah. To all of us he leaves the legacy of a life of scholarship, public service, and achievement, imbued with high standards and highlighted with elegance in verbal and written exposition, with good humor, and with enthusiasm and vitality for all his endeavors.

Acknowledgments: The following persons provided information for which we are grateful: Lisette K. Crowcroft, Christopher Crowcroft, Simon Crowcroft, K. Adamczewska-Andrzejewska, R. Andrzejewski, R. J. Berry, P. Jewell, and G. B. Rabb.

\section{References}

Andrzejewski R., Petrusewicz K. and Walkowa W. 1959. Preliminary report on results obtained with a living trap in a confined population of mice. Bulletin of the Polish Academy of Sciences Cl. II 7: 367-370.

Andrzejewski R. 1984. [The achievements of Professor Kazimierz Petrusewicz (1906-1982) in the domain of population ecology]. Wiadomości Ekologiczne 30: 27-40. [In Polish]

Caboń K. 1956. Untersuchungen über saisonale Veränderlichkeit des Gehirnes bei der kleinen Spitzmaus (Sorex minutus minutus L.). Annales Universitatis Mariae Curie-Skłodowska, Sectio C 10: $93-115$.

Crowcroft P. 1957. The life of the shrew. Max Reinhardt, London: 1- 166.

Crowcroft P. 1964. Note on the sexual maturation of shrews (Sorex araneus Linnaeus, 1758) in captivity. Acta Theriologica 8: 89-93.

Crowcroft P. 1966. Mice all over. G. T. Foulis \& Co., London: 1-121.

Crowcroft P. 1987. A note on the gestation period of the Dehnel/Petrusewicz Memorial Fund. Acta Theriologica 32: 511-512.

Crowcroft P. 1991. Elton's Ecologists, a history of the Bureau of Animal Population. University of Chicago Press, Chicago: 1-177. 
Crowcroft P. and Ingles J. M. 1959. Seasonal changes in the brain-case of the common shrew (Sorex araneus L.). Nature 183: 907-908.

Dehnel A. 1949. Badania nad rodzajem Sorex L. [Studies on the genus Sorex L.]. Annales Universitatis Mariae Curie-Skłodowska, Sectio C 4: 17-97. [In Polish with English summary]

Dehnel A. 1950. Badania nad rodzajem Neomys Kaup. [Studies on the genus Neomys Kaup.]. Annales Universitatis Mariae Curie-Skłodowska, Sectio C 5: 1-63. [In Polish with Russian and English summaries]

Dehnel A. 1952. Biologia rozmnażania ryjówki $S$. araneus L. w warunkach laboratoryjnych. [The biology of breeding of common shrew S. araneus L. in laboratory conditions. ]. Annales Universitatis Mariae Curie-Skłodowska, Sectio C 6: 359-376. [In Polish with Russian and English summaries]

Lidicker W. Z., Jr 1984. Kazimierz Petrusewicz, 1906-1982. Journal of Mammalogy 65: 168-170.

Pucek Z. 1955. Untersuchungen über die Veränderlichkeit des Schädels im Lebenszyklus von Sorex araneus araneus L. Annales Universitates Mariae Curie-Skłodowska, Sectio C 9: 163-211.

Pucek Z. 1957. Histomorphologische Untersuchungen über die Winterdepression des Schädels bei Sorex L. und Neomys Kaup. Annales Universitatis Mariae Curie-Skłodowska, Sectio C 10: $399-428$.

Pucek Z. 1964. August Dehnel, his life and work. Acta Theriologica 8: 1-10.

Schubarth H. 1958. Zur Variabilität von Sorex araneus araneus L. Acta Theriologica 2: 175-202.

William Z. LIDICKER, Jr, Museum of Vertebrate Zoology, University of California, Berkeley, CA 94720, USA

and

Zdzisław PUCEK, Mammal Research Institute, Polish Academy of Sciences, 17-230 Białowieża, Poland 